\title{
Penerapan Algoritma K-Means untuk Segmentasi Konsumen Menggunakan R
}

\author{
Karina Auliasari $^{1}$, Mariza Kertaningtyas ${ }^{2}$ \\ 1,2 Fakultas Teknologi Industri, Institut Teknologi Nasional Malang \\ J1. Raya Karanglo Km. 2, Malang \\ email: karina.auliasari86@gmail.com, mariza_kertaningtyas@lecturer.itn.ac.id
}

\begin{abstract}
ABSTRAK - Means merupakan salah satu teknik analisis data yang digunakan untuk mengelompokkan konsumen berdasarkan beberapa variabel, dimana teknik ini menjadi sangat handal ketika konsumen berinteraksi dengan produk yang ditawarkan. Teknik ini juga membantu perusahaan dalam memodelkan hubungan antara kecenderungan produk yang dibeli konsumen yang mungkin tidak diperhatikan oleh pihak perusahaan sebelumnya. Dengan demikian, penelitian ini berfokus pada penargetan konsumen yang menguntungkan dengan analisis cluster dan upaya untuk mengklasifikasikan konsumen dari perusahaan berdasarkan karakteristiknya menggunakan algoritma K-Means menggunakan bahasa pemrograman R. Dari hasil cluster dataset konsumen PT. Super Sukses Niaga pada tahun 2018 menunjukkan bahwa konsumen yang paling berpotensial ada pada cluster 2, di mana cluster 2 memiliki nilai rata-rata Total_Belanja_Setahun paling tinggi yaitu 4198.6656. Pada cluster 2 ini konsumen didominasi oleh jenis usaha PT karena nilai rata-rata Jenis.1 bernilai 1.667 yang mendekati nilai 2 (di mana nilai 2 merupakan label untuk jenis usaha PT). Hal serupa juga dihasilkan dari nilai rata-rata Lokasi.1 pada cluster 2 yang bernilai 1.667 yang mendekati nilai 2 (di mana nilai 2 merupakan label untuk lokasi pulau Kalimantan). Oleh karena itu, dapat disimpulkan konsumen yang memiliki nilai tinggi dalam melakukan transaksi adalah PT. BIS INDUSTRI, PT. REA KALTIM dan CV. MEDCO MINING pada cluster 2.
\end{abstract}

\section{Kata Kunci: Segmentasi, Konsumen, K-Means, R.}

ABSTRACT - Means is often used to clustering consumers and the company's market share. This technique is used to group consumers based on several variables, where this technique becomes very reliable when consumers interact with the products offered. This technique also helps companies model the relationship between the tendency of products purchased by consumers that may not have been noticed by the company before. This study focuses on targeting profitable consumers with cluster analysis based on their characteristics using the K-Means algorithm and the $R$ programming language. The results shows that the most potential consumers are in cluster 2, where cluster 2 has the highest value of Total_Belanja_Setahun, which is 4198.6656. In cluster 2, consumers are dominated by PT type of business because the average value of Jenis.1 is 1,667 which is close to 2 (where 2 is a label for PT). The same thing is also produced from the average value of Lokasi.1 in cluster 2 which is 1,667 which is close to 2 (where 2 is a label for Kalimantan). Therefore, it can be concluded that consumers who have high value in conducting transactions are PT. BIS INDUSTRI, PT. REA KALTIM and CV. MEDCO MINING on cluster 2.

Keywords: Segmentation, Customer, K-Means, $R$. 


\section{PENDAHULUAN}

Dalam rangka mengidentifikasi konsumen yang berharga, beberapa perusahaan menerapkan customer relationship management (CRM). CRM sendiri merupakan serangkaian strategi bisnis yang digunakan perusahaan yang berfokus pada konsumen untuk menarik lebih banyak loyalitas konsumen dan membangun hubungan jangka panjang dan menguntungkan [1]. Penerapan CRM juga membantu perusahaan untuk meningkatkan nilai konsumen dan mencapai laba tinggi [2]. Segmentasi konsumen merupakan salah satu teknik dasar dalam langkah-langkah CRM [3] dan juga merupakan pengelompokan konsumen berdasarkan karakteristik yang serupa [4]. Dengan teknik segmentasi konsumen menjadi portofolio, perusahaan memperhatikan konsumen dalam berbagai aspek dan mengidentifikasi konsumen yang paling menguntungkan. Ini juga membantu perusahaan untuk membangun loyalitas dengan konsumen dengan mengembangkan dan menawarkan produk dan layanan yang konsumen inginkan dan membuat konsumen lama puas serta mampu menarik konsumen yang baru [5]. Segmentasi konsumen mengelompokkan data konsumen menjadi kelompok-kelompok konsumen tertentu dimana masing-masing kelompok memiliki karakteristik yang serupa yang terkait dengan pemasaran produk, seperti umur, jenis kelamin, kecenderungan memilih produk tertentu ataupun seberapa banyak uang yang dikeluarkan konsumen dalam berbelanja. Segmentasi konsumen menjadi cara yang handal dalam mengidentifikasi pangsa pasar suatu perusahaan. Dengan menggunakan data konsumen perusahaan kemudian dapat merencanakan strategi seperti meningkatkan layanan, memberikan promosi yang menarik atau mengembangkan produk baru. Mampu mengelompokkan konsumen memungkinkan perusahaan untuk lebih memahami konsumen lebih jauh lagi mengetahui siapa saja yang menjadi target konsumen dengan cara yang lebih efisien. Pada umumnya perusahaan memberi label secara manual pada konsumen sebagai pembeda berdasarkan kebiasaan belanja yang dapat diamati. Hal ini memungkinkan terjadi kesalahan atau bias bila dilakukan oleh manusia.

Oleh karena itu peran komputer dalam mengelompokkan konsumen sangat dibutuhkan. Komputer akan mengelompokkan berdasarkan beberapa variabel yang disebut sebagai klasifikasi tanpa pengawasan (unsupervised learning) dan menjadi sangat handal ketika konsumen berinteraksi dengan produk yang ditawarkan dalam berbagai cara. Teknik ini membantu dalam memodelkan hubungan antara tindakan dan kepribadian konsumen yang mungkin tidak diperhatikan sebelumnya. Beberapa penelitian dilakukan mengunakan teknik clustering untuk mengidentifikasi konsumen, diantaranya penelitian yang dilakukan oleh Dursun dan Caber di tahun 2016, dimana dalam penelitian ini menggunakan algoritma self organizing maps (SOM) untuk menentukan jumlah cluster pada dataset konsumen hotel yang berada di Antalya Turki. Dari hasil penelitian Dursun dan Caber dihasilkan cluster-cluster konsumen berdasarkan data profil konsumen yang menghasilkan variable-variabel berdasarkan analisis RFM (Recency of the last purchases, Frequency of the purchases, dan Monetary value of the purchases) [6]. Dalam beberapa penelitian, kombinasi RFM (Recency of the last purchases, Frequency of the purchases, dan Monetary value of the purchases) dan berbagai metode pengelompokan telah digunakan untuk mengelompokkan pelanggan. Cheng et al. (2009) mengusulkan model pengelompokan dua tahap untuk mengklasifikasikan pasien dari rumah sakit. Data pasien dianalisis dengan RFM kemudian mereka menggunakan KMeans untuk mengklasifikasikan departemen rumah sakit dan akhirnya mengidentifikasi departemen yang menghasilkan laba tertinggi [7]. Berbagai macam teknik telah digunakan 
untuk segmentasi konsumen, karena sejumlah besar data yang diperoleh setiap hari dari konsumen, teknik data mining seperti algoritma clustering telah banyak digunakan untuk segmentasi konsumen. Data Science sendiri merupakan keilmuan yang semakin dibutuhkan saat ini. Berangkat dari kebutuhan akan keilmuan data science maka ada beberapa bahasa pemrograman open source yang ikut berkembang karena banyak digunakan untuk mengaplikasikan data science. Salah satu dari beberapa dari bahasa pemrograman tersebut adalah $\mathrm{R}$, dimana berdasarkan peringkat IEEE bahasa pemrograman $\mathrm{R}$ menempati peringkat kelima terpopuler setelah $\mathrm{C}++$ untuk analisis data [8]. Ini menunjukkan bahwa Bahasa pemrograman $\mathrm{R}$ unggul jika dibandingkan dengan pesaingnya seperti Python dan $C$ [8]. Bahasa pemrograman $\mathrm{R}$ juga didukung oleh banyak paket library analisis data yang tersedia pada repository CRAN (Comprehensive $R$ Archive Network) yang dibuat dan dikembangkan oleh komunitas yang sangat aktif [9]. Dengan demikian, penelitian ini berfokus pada penargetan konsumen yang menguntungkan dengan analisis cluster dan upaya untuk mengklasifikasikan konsumen dari perusahaan berdasarkan karakteristiknya menggunakan algoritma K-Means menggunakan bahasa pemrograman $R$. Segmentasi konsumen dapat membantu manajer untuk menghasilkan strategi CRM yang tepat untuk setiap kelompok konsumen dan dan dapat diterapkan pada CRM.

Algoritma K-Means diperkenalkan oleh J.B. MacQueen pada tahun 1976. Metode ini mempartisi data ke dalam cluster (kelompok) sehingga data yang memiliki karakteristik yang sama dikelompokkan ke dalam cluster yang sama dan data yang mempunyai karakteristik berbeda dikelompokkan ke dalam kelompok yang lain [10]. Berikut adalah langkah-langkah dari algoritma K-Means [10]:

Step 1 : Menentukan banyak K-cluster yang ingin dibentuk.

Step 2 : Membangkitkan nilai random untuk pusat cluster awal (centroid) sebanyak k.
Step 3 : Menghitung jarak setiap data input terhadap masing-masing centroid menggunakan rumus jarak Eucledian (Eucledian Distance) hingga ditemukan jarak yang paling dekat dari setiap data dengan centroid. Berikut adalah persamaan Eucledian Distance (persamaan 1):

$$
\mathrm{d}\left(x_{i}, \mu_{j}\right)=\sqrt{\left(\mathrm{x}_{\mathrm{i}}-\mu_{\mathrm{j}}\right)^{2}}
$$

Step 4 : Mengklasifikasikan setiap data berdasarkan kedekatannya dengan centroid (jarak terkecil).

Step 5 : Mengupdate nilai centroid. Nilai centroid baru diperoleh dari rata-rata cluster yang bersangkutan dengan menggunakan rumus yang ditunjukkan pada persamaan 2:

$$
\mu_{j}(\mathrm{t}+1)=\frac{1}{N_{S j}} \sum_{j=S j} x_{j}
$$

dimana:

$$
\begin{aligned}
& \mu_{\mathrm{j}}(t+1)=\text { centroid baru pada iterasi ke } \\
& (t+1), \\
& \mathrm{N}_{\mathrm{Sj}}=\text { banyak data pada cluster } \mathrm{S}_{\mathrm{j}}
\end{aligned}
$$

Step 6: Melakukan perulangan dari langkah 2 hingga 5 hingga anggota tiap cluster tidak ada yang berubah.

Step 7 : Jika langkah 6 telah terpenuhi, maka nilai rata-rata pusat cluster $\left(\mu_{\mathrm{j}}\right)$ pada iterasi terakhir akan digunakan sebagai parameter untuk Radial Basis Function yang ada di hidden layer.

\section{METODOLOGI PENELITIAN}

Beberapa tahapan yang dilakukan untuk melakukan segmentasi data konsumen sehingga perusahaan mampu mengenal konsumennya dengan lebih baik. Tahapan pertama adalah persiapan data tahap ini penting dilakukan karena dataset yang digunakan harus memiliki keseragaman tipe data berupa tipe data angka. Dalam tahapan pertama terdapat detail langkah-langkah yang harus dilakukan yaitu mengenal dataset yang digunakan, membaca dataset dengan fungsi read, membuat vector, mengubah data ke dalam bentuk matrix, menggabungkan data yang sebelumnya telah diubah, menormalisasi data, dan membuat data master. Tahap selanjutnya 
setelah persiapan data adalah tahap eksplorasi data, dimana dalam tahap ini diterapkan fungsi kmeans untuk selanjutnya dilakukan analisa hasil pengelompokkan. Dengan menganalisa hasil pengelompokkan data, nantinya dapat diketahui seperti apa kedekatan tiap titik data dari tiap kelompok yang terbentuk sehingga bisa menjadi inisiasi penetuan jumlah cluster yang optimal. Gambaran blok diagram tahapan penelitian dari tiap penjabarannya tadi ditunjukkan pada Gambar 1.

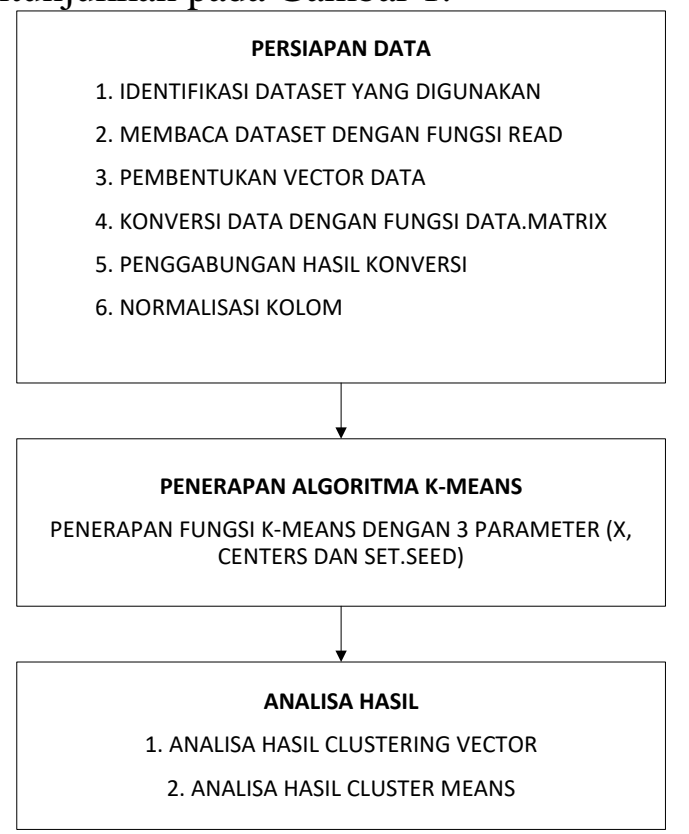

Gambar. 1 Tahapan segmentasi data

\section{Dataset yang digunakan}

Dataset yang digunakan dalam penelitian ini adalah data konsumen yang melakukan transaksi pembelian pada PT. Super Sukses Niaga pada tahun 2018 dengan lima atribut data yaitu Customer_ID, Nama_Pelanggan, Jenis, Lokasi, dan Total_Belanja_Setahun. Detail penjelasan dari keenam kolom tersebut ditunjukkan pada Tabel 1 .

Tabel 1. Atribut data konsumen dan deskripsi data

\begin{tabular}{|l|l|l|l|}
\hline \multicolumn{4}{|c|}{ Atribut tabel } \\
\hline No & Nama Atribut & $\begin{array}{l}\text { Tipe } \\
\text { Data }\end{array}$ & Deskripsi \\
\hline 1 & Customer_ID & $\begin{array}{l}\text { Charact } \\
\text { er \& } \\
\text { Integer }\end{array}$ & Kode \\
konsumen \\
\hline
\end{tabular}

\begin{tabular}{|l|l|l|l|}
\hline 2 & $\begin{array}{l}\text { Nama_Pelangga } \\
\mathrm{n}\end{array}$ & $\begin{array}{l}\text { Charact } \\
\text { er }\end{array}$ & $\begin{array}{l}\text { Nama } \\
\text { konsumen }\end{array}$ \\
\hline 3 & Jenis & $\begin{array}{l}\text { Charact } \\
\text { er }\end{array}$ & $\begin{array}{l}\text { Jenis } \\
\text { konsumen } \\
\text { (PT/CV) }\end{array}$ \\
\hline 4 & Lokasi & $\begin{array}{l}\text { Charact } \\
\text { er }\end{array}$ & $\begin{array}{l}\text { Lokasi } \\
\text { konsumen } \\
\text { (Kepulauan } \\
\text { ) }\end{array}$ \\
\hline 5 & $\begin{array}{l}\text { Total_Belanja_S } \\
\text { etahun }\end{array}$ & Integer & $\begin{array}{l}\text { Total } \\
\text { nominal } \\
\text { belanja } \\
\text { yang } \\
\text { dikeluarkan } \\
\text { konsumen } \\
\text { dalam } \\
\text { setahun } \\
\text { (dalam } \\
\text { satuan juta } \\
\text { rupiah) }\end{array}$ \\
\hline
\end{tabular}

Dari Tabel 1 terlihat jika tidak semua atribut data bertipe data angka, ada dua atribut yang bertipe data character yaitu Jenis dan Lokasi sisanya atribut Total_Belanja_Setahun bertipe data angka. Untuk atribut data Customer_ID dan Nama_Pelanggan dianggap unik karena kedua atribut dijadikan identitas data yang harus memiliki nilai unik yang mewakili tiap individu sehingga berbeda dari tiap baris data.

\section{Persiapan data}

Proses awal pada persiapan data adalah membaca dataset konsumen, pada penelitian ini bahasa pemrograman $\mathrm{R}$ yang digunakan akan secara otomatis membaca dataset dengan fungsi read. Dataset konsumen yang digunakan disini merupakan file teks dengan format .txt (data_konsumen_ssn.txt). Untuk membaca data_konsumen_ssn.txt digunakan fungsi read.csv, disini file csv merupakan format comma separated value, fungsi ini akan membaca isi dari file teks menjadi data.frame pada $\mathrm{R}$, hasil dari fungsi read.csv ditunjukkan pada Gambar 2, dimana ada beberapa baris data transaksi yang dilakukan konsumen PT. Super Sukses Niaga. 


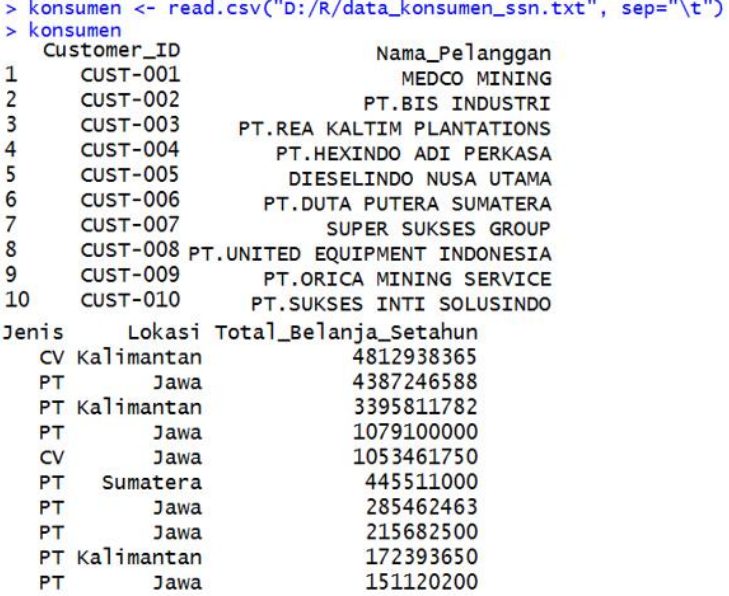

Gambar. 2 Tampilan fungsi read.csv

Seusai memanggil fungsi read.csv selanjutnya dilakukan pembentukan vector untuk atribut data Jenis, dan Lokasi sehingga dapat digunakan berulang kali dalam script R. Vector merupakan jenis data di bahasa pemrograman $\mathrm{R}$ dengan struktur data yang menyimpan deretan nilai (lebih dari satu nilai) dengan tipe data yang sama. Oleh karena itu, apabila suatu data bertipe data character maka seluruh data harus bertipe data character begitu pula sebaliknya jika tipe datanya angka maka keseluruhan data harus bertipe data angka. Vector didefinisikan dengan nama fuction yang hanya memiliki satu huruf saja yaitu $\mathbf{c}$. Setelah pembentukan vector, isi data dari dua atribut yaitu Jenis dan Lokasi yang bertipe data character harus diubah (dikonversi) menjadi tipe data numerik agar bisa digunakan dalam tahap penerapan algoritma K-Means. Untuk mengubah data pada vector menjadi tipe data numerik digunakan fungsi data.matrix. Fungsi data.matrix akan mengubah data pada kolom Jenis dan Lokasi yang diwakili oleh konsumen[c("Jenis", “Lokasi")] menjadi numerik. Setelah proses konversi ke angka, perlu dilakukan penggabungan data ke variabel asal, hal ini bertujuan untuk mempermudah proses segmentasi menggunakan metode K-Means. Untuk menggabungkan data hasil konversi (data.matrix) ke dalam data konsumen, digunakan kembali fungsi data.frame hal ini dikarenakan kolom Jenis dan Lokasi sudah ada maka ditambahkan akhiran .1 pada kolom Jenis dan Lokasi yang terdapat pada konsumen_matrix. Langkah pembentukan vector hingga menggabungkan hasil konversi ditunjukkan pada Gambar 3.

$>$ konsumen <- read.csv("D:/R/data_konsumen_ssn.txt", sep="\t")

$>$ konsumen_matrix <- data.matrix(konsumen[c("Jenis", "Lokasi")])

$>$ konsumen <- data.frame(konsumen, konsumen_matrix)

$>$ Lokasi <- unique(konsumen[c("Lokasi","Lokasi.1")])

$>$ Jenis <- unique(konsumen[c("Jenis","Jenis.1")])

Gambar. 3 Tampilan langkah pembentukan vector

Selanjutnya perlu dilakukan normalisasi data pada kolom Total_Belanja_Setahun dimana pada berisi data dengan nilai jutaan. Kolom Total_Belanja_Setahun digunakan untuk proses pengelompokkan oleh karena itu nilainya dinormalisasi agar mempermudah dan menyederhanakan perhitungan tanpa mengurangi tingkat akurasi, proses normalisasi data ini sangat penting dilakukan mengingat kemungkinan penambahan data konsumen di masa depan. Normalisasi data Total_Belanja_Setahun dilakukan dengan cara membagi data sehingga nilai jutaan menjadi puluhan.

\section{Penerapan Algoritma K-Means}

Data transaksi konsumen dibagi berdasarkan 3 kolom yaitu Jenis, Lokasi dan Total_Belanja_Setahun, ketiga kolom tersebut disimpan ke dalam sebuah vector field_yang_digunakan, selanjutnya dilakukan tahapan segmentasi terhadap data konsumen. Untuk melakukan segmentasi data konsumen digunakan fungsi kmeans menggunakan 3 parameter yaitu $\mathbf{x}$ sebagai data yang digunakan (keseluruhan data harus berupa numerik), centers yang merupakan jumlah cluster yang diinginkan dan nstart yaitu jumlah kombinasi acak yang dihasilkan oleh library R. Pada fungsi kmeans disertai dengan pemanggilan fungsi seet.seed, fungsi ini untuk menyeragamkan daftar nilai acak yang sama dari algoritma KMeans sehingga didapatkan output yang sama. Urutan langkah baris program untuk mengelompokkan data konsumen PT. 
Super Sukses Niaga menggunakan algoritma K-Means diperlihatkan pada Gambar 4. Pada Gambar 4 ketika baris program $\mathrm{R}$ berhasil dieksekusi didapatkan empat hasil yang masing-masing telah dilabeli dengan angka 1 sampai dengan 4 . Label nomor 1 menunjukkan ada tiga kelompok/cluster yang masing-masing cluster memiliki jumlah titik data yang berbeda, label nomor 2 menunjukkan nilai rata-rata (centroid) dari tiap cluster, label nomor 3 merupakan pembagian cluster dari tiap elemen data berdasarkan posisi data dan terakhir label nomor 4 sebagai jumlah jarak kuadrat dari tiap titik ke centroid.

$>$ konsumenSTotal_Belanja_Setahun <- konsumenSTotal_Belanja_Setahun/1000000 $>$ kolom_yang_digunakan = c("Jenis.1", "Lokasi.1","Total_Belanja_Setahun") $>$ set. $\operatorname{seed}(100)$

> segmentasi <- kmeans ( $\mathrm{x}=$ konsumen [field_yang_digunakan], centers=3, nstart=25) $>$ segmentasi

K-means clustering with 3 clusters of sizes 2, 3, 161

Cluster means:

Jenis.1 Lokasi.1 Total_Belanja_Setahun

$1.5000001 .000000 \quad 1066.2809$

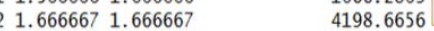

$31.8750001 .500000 \quad 113.8933$

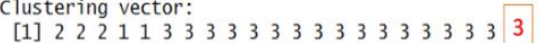

Within cluster sum of squares by cluster:

[1] $\quad 329.1599 \quad 1057469.4053 \quad 221657.33714$

(between_SS / total_SS = 97.1\%)

Gambar 4. Tampilan fungsi K-Means

\section{HASIL DAN PEMBAHASAN}

Jika diamati hasil dari cluster yang ditunjukkan pada Gambar 4 memperlihatkan hasil clustering vector, dimana merupakan rangkaian vector yang berisi angka cluster. Pada Gambar 5 vector berisi angka 1 sampai dengan 3 sesuai inputan jumlah cluster yang ingin dibentuk. Vector pada Gambar 5 dimulai dari angka 2, yang artinya data pertama dari dataset konsumen dialokasikan pada cluster nomor 2. Dari Gambar 5 juga terlihat isi vector keempat bernilai 1, ini menunjukkan bahwa data keempat dari keseluruhan dataset dialokasikan pada cluster nomor 1, dan seterusnya hingga posisi data terakhir (ke-21) memiliki cluster nomor 3.

\author{
Nomor cluster \\ untuk data pada \\ posisi ke-2 \\ clustering vector:
}

[1] $\begin{array}{lllllllllllll}2 & 2 & 2 & 1 & 1 & 3 & 3 & 3 & 3 & 3 & 3 & 3\end{array}$

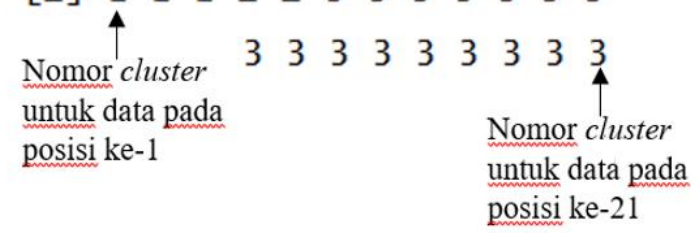

Gambar 5. Hasil clustering vector

Pada hasil clustering algoritma K-Means seperti yang ditunjukkan Gambar 3, bagian awal menunjukkan K-Means clustering with 3 clusters of sizes 2, 3, 16, ini artinya menggunakan algoritma K-Means dataset konsumen telah dibagi menjadi 3 cluster. Tiga cluster yang telah dibagi tadi masing-masing cluster ke-1 memiliki 2 data, cluster ke-2 memiliki 3 data dan cluster ke-3 memiliki 16 data, dimana jumlah total data 21 data yang merupakan jumlah total dataset konsumen. Jika ingin melihat vector mana saja yang masuk ke dalam masing-masing cluster maka digunakan fungsi which seperti yang ditunjukkan pada Gambar 6 hingga Gambar 8. Pada Gambar 6 memperlihatkan bahwa cluster 1 memiliki 2 data (data ke-4 dan ke-5), cluster 2 pada Gambar 7 memiliki 3 data (data ke-1, ke-2 dan ke-3) dan cluster 3 pada Gambar 8 memiliki 16 data (data ke-6 sampai dengan data ke-21).

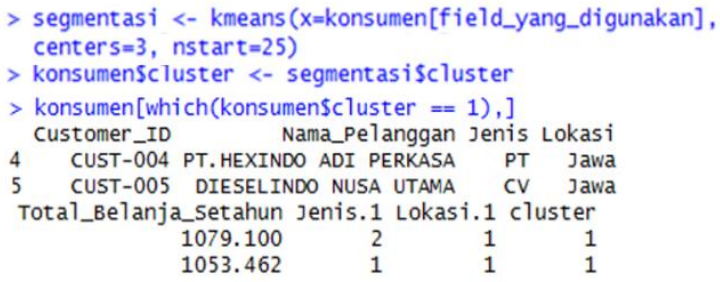

Gambar 6. Tampilan vector cluster 1

$>$ segmentasi <- kmeans ( $x=k$ konsumen[field_yang_digunakan], centers $=3$, nstart $=25$ )

$>$ konsumenscluster <- segmentasiscluster

$>$ konsumen [which (konsumenscluster $=2$ ), ]

Customer_ID Nama_Pelanggan Jenis Lokasi CUST-001 MEDCO MINING CV Kalimantan CUST-002 PT.BIS INDUSTRI PT Jawa CUST-003 PT. REA KALTIM PLANTATIONS PT Kalimantan Total_Belanja_setahun Jenis.1 Lokasi.1 cluster $\begin{array}{llll}4812.938 & 1 & 2 & 2 \\ 4387.247 & 2 & 1 & 2 \\ 3395.812 & 2 & 2 & 2\end{array}$

Gambar 7. Tampilan vector cluster 2 


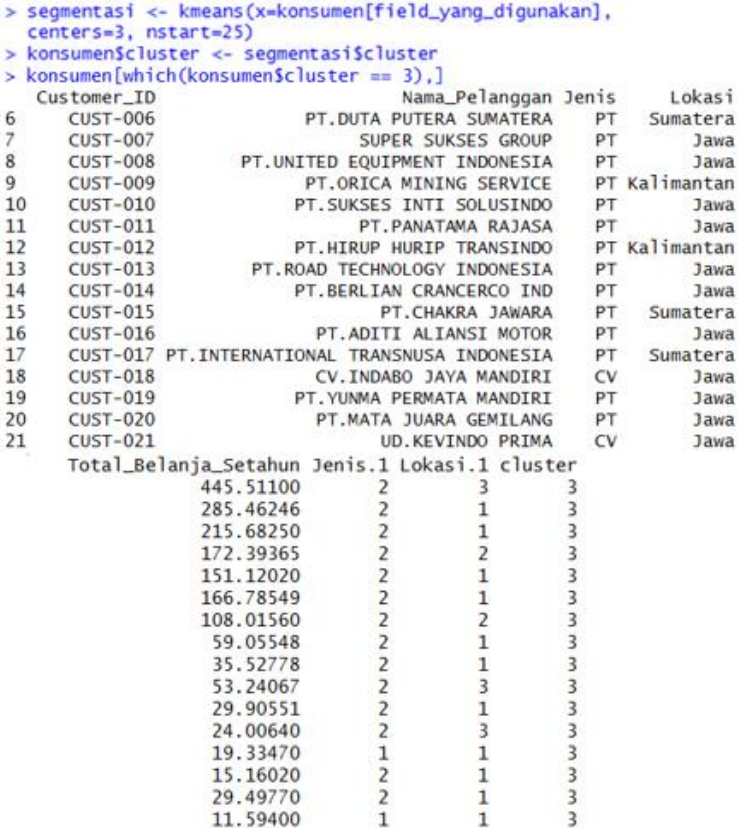

Gambar 8. Tampilan vector cluster 3

Hasil cluster mean yang ditunjukkan pada label nomor 2 pada Gambar 3, merupakan nilai rata-rata centroid dari seluruh titik data tiap cluster. Untuk kolom Jenis.1 menunjukkan nilai rata-rata dari data jenis usaha yang telah dirubah menjadi numerik dengan angka 1 mewakili CV dan angka 2 mewakili PT. Pada cluster 1 untuk kolom Jenis.1 (jenis usaha) terlihat bahwa nilai cluster mean bernilai 1.50 ini artinya bahwa data bersifat campuran (antara CV dan PT jumlahnya seimbang), sedangkan untuk cluster 2 dan 3 data lebih banyak cenderung berjenis usaha PT karena nilainya 1.67 dan 1.87 yang mendekati nilai 2 yang berjenis usaha PT. Pada kolom Lokasi.1 menunjukkan nilai rata-rata dari data lokasi konsumen yang juga telah diubah menjadi numerik dengan angka 1 mewakili pulau Jawa, angka 2 mewakili pulau Kalimantan dan angka 3 mewakili pulau Sumatera. Pada ketiga cluster terlihat bahwa lokasi konsumen cenderung ke pulau Jawa. Kolom terakhir yang dianalisa yaitu kolom Total_Belanja_Setahun memiliki nilai yang cukup signifikan pembagiannya untuk tiap cluster, dimana cluster ke-2 memiliki total belanja lebih tinggi dibandingkan cluster ke-1 dan ke-3. Data konsumen pada cluster ke-2 inilah yang bisa menjadi fokus untuk mempertahankan layanan dan pemasaran kepada konsumen pada cluster ke-2 dan perusahaan bisa meningkatkan pemasaran dan evaluasi pelayanan pada konsumen pada cluster 1 dan 3 .

\section{KESIMPULAN}

Dari hasil cluster dataset konsumen PT. Super Sukses Niaga pada tahun 2018 menunjukkan bahwa konsumen yang paling berpotensial ada pada cluster 2, di mana cluster 2 memiliki nilai rata-rata Total_Belanja_Setahun paling tinggi yaitu 4198.6656. Pada cluster 2 ini konsumen didominasi oleh jenis usaha PT karena nilai rata-rata Jenis. 1 bernilai 1.667 yang mendekati nilai 2 (di mana nilai 2 merupakan label untuk jenis usaha PT). Hal serupa juga dihasilkan dari nilai rata-rata Lokasi.1 pada cluster 2 yang bernilai 1.667 yang mendekati nilai 2 (di mana nilai 2 merupakan label untuk lokasi pulau Kalimantan). Oleh karena itu, dapat disimpulkan konsumen yang memiliki nilai tinggi dalam melakukan transaksi adalah PT. BIS INDUSTRI, PT. REA KALTIM dan CV. MEDCO MINING pada cluster 2.

Untuk penelitian segmentasi konsumen selanjutnya perlu dikembangkan pengujian cluster dengan beberapa nilai $\mathrm{K}$ untuk kemudian dilakukan pengujian hasil cluster terbaik berdasarkan variasi nilai $\mathrm{K}$.

\section{REFERENSI}

[1] Wu, S-I. and Lu, C-L. 2012. "The relationship between $C R M, R M$, and business performance:ca study of the hotel industry in Taiwan'. International Journal of Hospitality Management, Vol. 31, No. 1, pp.276-285.

[2] Thakur, R. and Workman, L. 2016. "Customer portfolio management (CPM) for improved customer relationship management (CRM): are your customers platinum, gold, silver, or bronze?'. Journal of Business Research, Vol. 69, No. 10, pp.40954102.

[3] Smith, B. 2007. "Marketing master class: excellence in medical marketing: origins, definition and precursors". 
Journal of Medical Marketing, Vol. 7, No. 1, pp.25-32.

[4] Chen, Y-S., Cheng, C-H., Lai, C-J., Hsu, C-Y. and Syu, H-J. 2012. "Identifying patients in target customer segments using a two stage clusteringclassification approach: a hospitalbased assessment". Computers in Biology and Medicine, Vol. 42, No. 2, pp.213-221.

[5] Wei, J-T., Lin, S-Y., Weng, C-C. and $\mathrm{Wu}, \mathrm{H}-\mathrm{H}$. 2012. "A case study of applying LRFM model in market segmentation of a children's dental clinic". Expert Systems with Applications, Vol. 39, No. 1, pp.55295533.

[6] A. Dursun dan M. Caber, "Using Data Mining Techniques for Profiling Profitable Hotel Customers:an Application of RFM Analysis, ". Tourism Management Perspectives, vol. 18, p. 153-160, 2016.

[7] Cheng, C-H. and Chen, Y-S. (2009) "Classifying the segmentation of customer value via RFM model and RS theory". Expert Systems with Applications, Vol. 36, No. 2, pp.41764184.

[8] B Stephen Cass. 2016. The 2016 top programming languages.

[Online]

http://spectrum.ieee.org/computing/ software/the-2016-top programming-languages.

[9] Tim Smith, Kevin Ushey. 2016. "Arrgh: a newcomer's (angry) guide to R". [Online] http://arrgh. timsmith.us/.

[10] Prasetyo E. 2014. "Data Mining Mengolah Data Menjadi Informasi Menggunakan MATLAB". Penerbit ANDI OFFSET, Yogyakarta. 